\title{
ANALISIS KEMAMPUAN MULTI REPRESENTASI PESERTA DIDIK PADA MATERI USAHA DI MADRASAH ALIYAH
}

\author{
${ }^{1 *}$ Rizki Murniati., ${ }^{2}$ Edy Tandililing, ${ }^{3}$ Muhammad Musa Syarif Hidayatullah \\ ${ }^{1}$ Mahasiswa Program Studi Pendidikan Fisika, Universitas Tanjungpura, Kota Pontianak, Indonesia \\ 2 Dosen Program Studi Pendidikan Fisika, Universitas Tanjungpura, Kota Pontianak, Indonesia \\ ${ }^{3}$ Dosen Program Studi Pendidikan Fisika, Universitas Tanjungpura, Kota Pontianak, Indonesia
}

*Email Korespondensi: rizkimurniatialfath@gmail.com

\section{INFO ARTIKEL}

Diterima :02 November 2020

Direvisi : -

Dipublikasikan : 31 Januari 2021

\begin{abstract}
A B STRACT
The purpose of this study to identify student's multi-representation ability about work at MA Negeri Bengkayang. The method used is the survey method without comparative group which is descriptive correlative with research instrument in the form of descriptive test on the multirepresentation ability test of five questions and multiple-choice test on the learning outcomes test often questions. the validity of the multi-representation test was 3.45 whit valid criteria and the validity of the learning outcomes test was 3.52 with valid criteria Meanwhile, the reliability of the multi-representation test was 0.516 in the sufficient category and the reliability of the learning outcomes test was 0.55 in the sufficient category. The study found that the multi-representation ability of students was low with an average percentage of $33.08 \%$. The multi-representation ability of students with the highest percentage is in the image to symbol representation type, which is $75 \%$, while the multi-representation ability of students with the lowest percentage is in the verbal to mathematical representation type, which is $5.19 \%$. This study also did not found a correlation ( $r_{\text {count }} 0.04>r_{\text {table }} 0.4848$ ) between multi-representation ability and student's learning outcomes. The result of this study is expected to be taken into consideration in determining learning strategies.
\end{abstract}

Keywords: Work, Multi-representation Ability, Learning Outcomes

\section{Pendahuluan}

Ilmu Pengaetahuan Alam (IPA) merupakan studi terkait cara mengeksplorasi alam secara terstruktur, sehingga IPA tidak hanya mengandung pengetahuan pengetahuan berupa fakta, konsep atau prinsip saja namun IPA juga merupakan proses penemuan (Permendiknas, 2006). Dalam mempelajari fisika, peserta didik dibiasakan untuk berpikir secara rasional, responsif dan teliti serta sistematis. Fisika merupakan ilmu pengetahuan yang mempelajari karakter, fenomena, interaksi gejala, energi serta hubungan sebab akibat dari suatu partikel subatomik (mikro kosmos) sampai pada system yang sangat besar (makro kosmos) (Lambaga, 2019).

Salah satu mata pelajaran yang dianggap sulit pada jurusan IPA yaitu fisika. Hal ini ditunjukkan dari perolehan hasil Ujian Nasioanl (UN) 2019 Fisika terkhusus pada indikator mengindentifikasi usaha yaitu 51,28 yang tergolong rendah (Puspendik, 2019). Hasil observasi ke sekolah, ditemukan bahwa hasil belajar peserta didik di MA Negeri Bengkayang khususnya pada materi usaha masih tergolong cukup dengan rata-rata nilai yaitu 64,2. Ketidakberhasilan ini dapat dipicu oleh kurangnya kemampuan peserta didik dalam merepresentasikan suatu bentuk konsep ke bentuk yang lain. 
Penelitian sebelumnya yang berkaitan dengan penelitian ini yaitu Analisis Pemahaman Konsep Siswa Berdasarkan Multi Representasi pada Materi Usaha dan Energi Kelas XI SMA Negeri 1 Banawa Tengah yang dilakukan oleh Nur Husnul Denyati pada tahun 2020 menunjukkan bahwa pemahaman konsep peserta didik berdasarkan multi representasi tergolong rendah dengan persentase sebesar 21,1\% pada representasi verbal; 26,1\% pada representasi gambar; $18,4 \%$ pada representasi matematis; dan 11,1\% pada representasi grafik.

Representasi merupakan suatu bentuk yang dapat mendeskripsikan sesuatu dalam bentuk yang lain (Goldin, 2002). Multi representasi yaitu merepresentasi kembali konsep yang sama dalam bentuk yang lain meliputi gambar, grafik dan matematik (Waldrip, 2006). Tiga fungsi utama multi representasi, yaitu (1) pelengkap; (2) pembatas interpretasi; (3) membangun pemahaman (Ainsworth, 1999).

Salah satu materi fisika yang memerlukan multi representasi untuk pemecahan masalahnya yaitu materi usaha. Proses usaha dan energi dapat dideskripsikan (digambarkan ulang) dalam bentuk verbal, gambar, diagram batang dan representasi matematika (Heuvele dan Zou, 2001). Materi usaha merupakan salah satu materi yang penerapannya sering kita temukan pada aktivitas sehari-hari. Misalnya ketika kita mendorong sebuah meja dan ingin mengetahui besar usaha yang kita lakukan terhadap meja tersebut, maka kita memerlukan bentuk-bentuk representasi yang dapat memvisualisasikan makna tersebut dalam bentuk lain. Misalnya dengan merepresentasikannya ke bentuk sketsa gambar, kemudian menentukan symbol-simbol besaran terkait yang akan direpresentasikan ke bentuk persamaan matematis untuk mencari besarnya usaha yang dilakukan.

Selain mendeskripsikan profil kemampuan multi representasi peserta didik, penelitian ini juga membahas korelasi antara kemampuan multi representasi peserta didik terhadap hasil belajar. Berdasarkan studi yang dilakukan oleh Haratua dan Judyanto (2016) menemukan bahwa peserta didik yang mendahului proses pemecahan masalahnya dengan penggambaran berupa sketsa atau diagram lebih berhasil daripada peserta didik yang langsung menggunakan persamaan matematis. Sehingga, keberhasilan peserta didik dalam memecahkan permasalahan fisika perlu diimbangi dengan keberhasilan peserta didik dalam memahami dan menggunakan multi representasi.

Dengan demikian, tujuan dilakukannya penelitian ini yaitu untuk menganalisis kemampuan multi representasi peserta didik pada materi usaha di MA Negeri Bengkayang. Sehingga diharapkan dapat menjadi referensi dalam merancang proses pembelajaran di kelas.

\section{Metode Penelitian}

Dalam penelitian ini, metode yang digunakan yaitu metode survey. Data yang digunakan dalam penelitian ini merupakan data murni bukan data dari hasil adanya perlakuan peneliti. Populasi dalam penelitian ini adalah seluruh peserta didik kelas XI IPA di MA Negeri Bengkayang Tahun Pelajaran 2020/2021 dengan pengambilan sampel menggunakan teknik sampel total, dimana seluruh anggota populasi dijadikan sebagai sampel (Sugiyono, 2018). Sampel penelitian ini adalah peserta didik kelas XI IPA MA Negeri Bengkayang Tahun Pelajaran 2020/2021 yang berjumlah 35 orang.

Penelitian ini menggunakan instrumen berbentuk soal uraian berjumlah 5 soal pada tes kemampuan multi representasi dan soal pilihan ganda berjumlah 10 soal pada tes hasil belajar. Instrumen penelitian ini divalidasi oleh tiga orang validator yaitu dua orang dosen Pendidikan Fisika FKIP Untan dan satu orang guru mata pelajaran Fisika SMA Negri 9 Pontianak. Validitas instrumen yang diperoleh dari hasil validasi tergolong valid. Sedangkan, hasil uji coba soal yang dilakukan di kelas XI IPA MA Negeri Bengkayang Tahun Pelajaran 2019/2020 diperoleh keterangan bahwa tingkat reabilitas untuk soal tes tergolong sedang.

Langkah dalam penelitian ini terdiri dari tiga tahap, yaitu persiapan, pelaksanaan dan akhir. Hal-hal yang dilakukan pada tahap persiapan yaitu: (1) kajian literatur, (2) kajian lapangan, (3) merumuskan masalah dan penyusunan 
proposal penelitian, (4) penyusunan instrumen penelitian, (5) seminar proposal penelitian, (6) memvalidasi instrumen, (7) memperbaiki instrumen setelah validasi, (8) melakukan uji coba soal, dan (9) melakukan perhitungan reliabilitas instrumen. Kemudian hal-hal yang dilakukan pada tahap pelaksanaan yaitu : (1) mempersiapkan peserta didik yang akan diteliti secara daring melalui e-learning madrasah dengan bantuan Guru Fisika di MA Negeri Bengkayang, dan (2) memberikan link google form soal penelitian melalui e-learning madrasah untuk mengetahui kemampuan multi representasi dan hasil belajar peserta didik. Hal-hal yang dilakukan pada tahap akhir yaitu: (1) melakukan analisis jawaban peserta didik, (2) melakukan pengolahan data berdasarkan hasil analisis, (3) menarik kesimpulan atas analisis jawaban yang telah dilakukan, dan (4) menyusun laporan akhir penelitian.

\section{Hasil dan Pembahasan}

\subsection{Hasil}

Kemampuan multi representasi peserta didik dapat dilihat dari persentase yang dicapai dalam menyelesaikan soal tes kemampuan multi representasi. Hasil analisis profil kemampuan multi representasi peserta didik pada materi usaha disajikan pada Tabel 1.

Tabel 1. Profil Kemampuan Multi Representasi Peserta Didik

\begin{tabular}{|c|c|c|c|c|c|}
\hline $\begin{array}{c}\text { Tipe } \\
\text { Representasi }\end{array}$ & $\begin{array}{c}\text { Nomor } \\
\text { Soal }\end{array}$ & $\begin{array}{c}\text { Perolehan skor } \\
\text { peserta didik }\end{array}$ & $\begin{array}{l}\text { Skor } \\
\text { ideal }\end{array}$ & $\begin{array}{c}\text { Perolehan skor } \\
\text { peserta didik/skor } \\
\text { ideal }\end{array}$ & $\begin{array}{l}\text { Kemampuan multi } \\
\text { representasi (\%) }\end{array}$ \\
\hline \multirow{2}{*}{$V-G$} & 1 & \multirow{2}{*}{14} & \multirow{2}{*}{112} & \multirow{2}{*}{0,1250} & \multirow{2}{*}{$12,50 \%$} \\
\hline & 2 & & & & \\
\hline \multirow{5}{*}{ V-S } & 1 & \multirow{5}{*}{253} & \multirow{5}{*}{392} & \multirow{5}{*}{0,6454} & \multirow{5}{*}{$64,54 \%$} \\
\hline & 2 & & & & \\
\hline & 3 & & & & \\
\hline & 4 & & & & \\
\hline & 5 & & & & \\
\hline \multirow{2}{*}{ V-M } & 1 & \multirow{2}{*}{16} & \multirow{2}{*}{308} & \multirow{2}{*}{0,0519} & \multirow{2}{*}{$5,19 \%$} \\
\hline & 2 & & & & \\
\hline \multirow{2}{*}{ G-V } & 3 & \multirow{2}{*}{19} & \multirow{2}{*}{56} & \multirow{2}{*}{0,3393} & \multirow{2}{*}{$33,93 \%$} \\
\hline & 4 & & & & \\
\hline \multirow{2}{*}{ G-S } & 3 & \multirow{2}{*}{168} & \multirow{2}{*}{224} & \multirow{2}{*}{0,7500} & \multirow{2}{*}{$75,00 \%$} \\
\hline & 4 & & & & \\
\hline \multirow{2}{*}{ G-M } & 3 & \multirow{2}{*}{25} & \multirow{2}{*}{280} & \multirow{2}{*}{0,0893} & \multirow{2}{*}{$8,93 \%$} \\
\hline & 4 & & & & \\
\hline Gk-V & 5 & 13 & 28 & 0,4643 & $46,43 \%$ \\
\hline Gk-S & 5 & 56 & 168 & 0,3333 & $33,33 \%$ \\
\hline Gk-M & 5 & 10 & 56 & 0,1786 & $17,86 \%$ \\
\hline
\end{tabular}

Kemampuan multi representasi peserta didik di MA Negeri Bengkayang bervariasi dengan pencapaian ratarata 33,08\%. Persentase tertinggi yang diperoleh peserta didik terdapat pada tipe representasi gambar ke simbol (G-S) yaitu sebesar 75\% sedangkan persentase terendah yang diperoleh peserta didik terdapat pada tipe representasi verbal ke matematis (V-M) yaitu sebesar 5,19\%. Terdapat banyak peserta didik yang keliru dalam 
merepresentasikan peristiwa yang disajikan dalam bentuk verbal yang kemudian diminta untuk direpresentasikan ke dalam bentuk matematis.

Korelasi antara kemampuan multi representasi dengan hasil belajar peserta didik dianalisis dengan uji korelasi Spearman karena data yang digunakan tidak berdistribusi normal setelah diuji dengan uji normalitas Kolmogorov-Smirnov. Kemuadian analisis data dilanjutkan dengan uji korelasi Spearman yang menunjukkan signifikasi hubungan kemampuan multi representasi dengan hasil belajar diperoleh nilai siginifikansi (2-tailed) sebesar 0,982 atau $\mathrm{P}>0,05$ ( $\mathrm{H}_{0}$ diterima) yang berarti tidak terdapat hubungan yang signifikan antara variabel kemampuan multi representasi peserta didik terhadap hasil belajar. Berdasarkan nilai $r_{\text {hitung, }}$ diketahui nilai $r_{\text {hitung }}$ untuk kemampuan multi representasi $(X)$ dengan hasil belajar $(Y)$ sebesar 0,04 sedangkan $r_{\text {tabel }}$ sebesar 0,4828 maka dapat disimpulkan $r$ hitung $<r$ tabel yang berarti tidak terdapat korelasi positif antara kemampuan multi representasi dengan hasil belajar. Rangkuman hasil uji korelasi Spearman disajikan dalam Tabel 2.

Tabel 2. Hasil Uji Korelasi Spearman Kemampuan Multi Representasi dan Hasil Belajar Peserta Didik

\begin{tabular}{|c|c|c|c|c|c|}
\hline Korelasi Spearman & $\begin{array}{c}\text { Jumlah } \\
\text { peserta didik } \\
\text { (n) }\end{array}$ & $\begin{array}{l}\text { Koefisien } \\
\text { korelasi (r) }\end{array}$ & $r_{\text {tabel }}$ & $\begin{array}{l}\text { Nilai } \\
\text { sig.(2- } \\
\text { tailed) }\end{array}$ & $P$ \\
\hline $\begin{array}{l}\text { Kemampuan Multi } \\
\text { Representasi (X) }\end{array}$ & 28 & 0,04 & 0,4828 & 0,982 & $>0,05$ \\
\hline Hasil Belajar (Y) & 28 & & & & \\
\hline
\end{tabular}

\subsection{Pembahasan}

Multi representasi yaitu merepresentasi kembali konsep yang sama dalam bentuk yang lain meliputi gambar, grafik dan matematik (Waldrip, 2006). Rata-rata kemampuan multi representasi yang dicapai oleh peserta didik tergolong rendah dengan persentase sebesar 33,08\% dari persentase yang diharapkan yaitu 100\%. Berdasarkan hasil analisis jawaban peserta didik dalam membentuk representasi yang dimaksud, sebagian besar kemampuan representasi peserta didik belum mampu menunjang proses belajar fisika karena kekeliruan dalam merepresentasikan suatu konsep dapat mengakibatkan kesalahan pada proses atau hasil pemecahan masalah dan kesalahan dalam memahami suatu konsep. Kurangnya pemahaman peserta didik dalam membentuk macammacam representasi dalam fisika menjadi penyebab kekeliruan yang dilakukan oleh peserta didik. Menurut Leigh (2004) menyatakan bahwa peserta didik bisa mengerjakan soal karena mencontoh penyelesaian masalah yang ada buku-buku teks atau soal latihan yang diberikan guru, tetapi tidak mampu untuk menerapkan penyelesaian dari satu persoalan ke persoalan yang lain walaupun dengan jenis soal yang sama.

Berdasarkan data yang diperoleh kemampuan representasi peserta didik dengan kategori sedang terdapat pada tipe representasi gambar ke simbol (G-S) dengan persentase sebesar 75\%, sedangkan kemampuan multi representasi peserta didik dengan kategori rendah terdapat pada tipe representasi verbal ke matematis (V-M) dengan persentase sebesar 5,19\%. Temuan ini sejalan dengan penelitian yang dilakukan oleh Reva (2016) menemukan sebagian peserta didik salah dalam penggunaan rumus matematik, salah dalam memasukkan data ke persamaan matematis dan salah dalam melakukan perhitungan. Berdasarkan penelitian yang dilakukan Haratua dan Judyanto (2016) menemukan bahwa umumnya dalam menyelesaikan soal peserta didik langsung ke persamaan matematis tanpa mendeskripsikan masalah dalam bentuk sketsa atau gambar yang mengakibatkan beberapa dari mereka tidak berhasil menyelesaikan masalah.

Representasi yang dibentuk oleh peserta didik terdapat lima jenis, yaitu: (a) representasi verbal yaitu konsep fisika yang disajikan dalam bentuk kalimat; (b) representasi simbol yaitu lambang-lambang dalam besaran fisika pada materi usaha yang disertakan dengan satuan yang tepat; (c) representasi gambar yaitu sketsa peristiwa usaha yang disertakan dengan besaran yang terkait dengan peristiwa tersebut; (d) representasi grafik yaitu diagram gaya terhadap perpindahan benda yang disertakan dengan besaran yang terkait dengan representasi yang disajikan; 
(e) representasi matematis yaitu penyajian konsep fisika dalam persamaan (rumus-rumus). Setiap representasi dibentuk oleh satu sampai tiga representsi yang disajikan yaitu representasi verbal, gambar dan grafik sehingga terdapat sembilan tipe representasi yang di teliti. Profil kemampuan multi representasi peserta didik disajikan dalam Tabel 3 .

Tabel 3. Profil Kemampuan Multi Representasi Peserta Didik Tiap Indikator

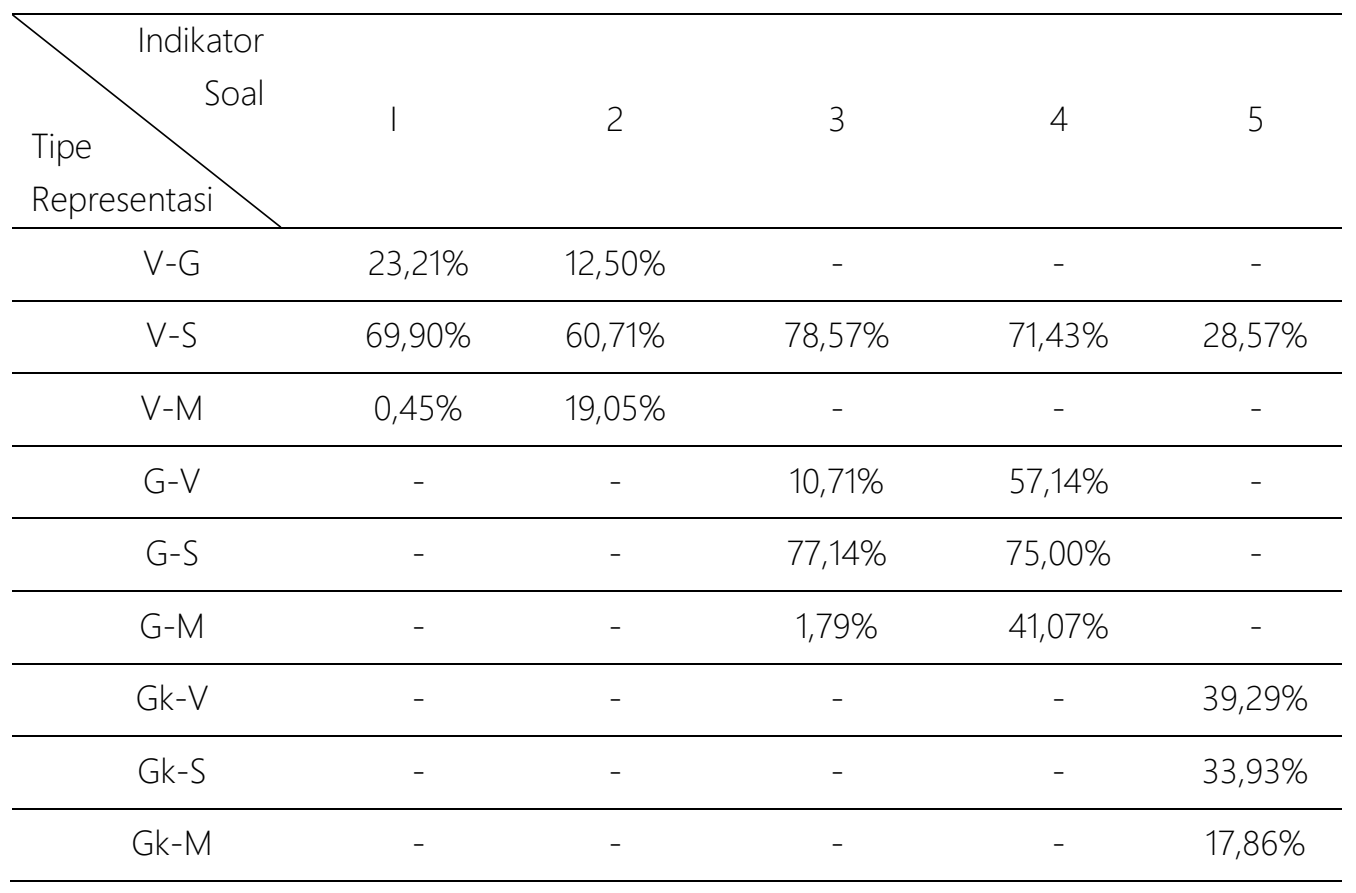

Pada indikator pertama, representasi yang dibentuk peserta didik dengan persentase terendah yang diperoleh yaitu dalam merepresentasikan bentuk verbal kebentuk matematis. Hal ini disebabkan karena sejumlah peserta didik langsung menuliskan persamaan matematis tanpa menganalisis soal melalui sketsa gambar atau keliru dalam merepresentasikan pernyataan ke dalam bentuk gambar sehingga persamaan matematis yang digunakan tidak tepat untuk menyelesaikan soal. Hal ini relevan dengan ptemuan Reva (2016), yang menemukan bahwa seluruh peserta didik salah menyelesaikan soal usaha pada bidang miring. Peserta didik langsung menggunakan persamaan matematis setelah menulis data dan pertanyaan dalam soal yang disajikan. Padahal dalam menyelesaikan soal ini sangat memerlukan penggunaan representasi fisis berupa analisis diagram benda bebas dan pemahaman prinsip penyelesaian soal, akibatnya seluruh peserta didik keliru dalam menggunakan rumus dan salah memasukkan data serta tanda ke rumus matematis.

Pada indikator kedua, persentase terendah yang diperoleh peserta didik yaitu dalam merepresentasikan bentuk verbal kebentuk gambar, yang mana sebagian peserta didik tidak menggambarkan sketsa kejadian yang dimaksud atau keliru dalam merepresentasikan gambar dari representasi verbal. Hal ini relevan dengan temuan Nur (2020) yang menemukan bahwa peserta didik lebih sulit membentuk representasi yang dibentuk oleh representasi verbal dan lebih sulit untuk memahami konsepnya dengan alasan bahwa konsep terlalu sulit untuk diartikan, serta lebih memilih untuk menyelesaikan perhitungan matematis.

Pada indikator ketiga, persentase terendah yang diperoleh peserta didik yaitu dalam merepresentasikan bentuk gambar kebentuk matematis. Sebagian peserta didik tidak memahami gambar yang disajikan sehingga salah dalam memilih persamaan yang digunakan untuk menyelesaikan soal. Hal ini sesuai dengan temuan Reva (2016) yang menemukan bahwa seluruh peserta didik salah dalam menggunakan rumus, salah memasukkan data dan tanda ke rumus matematis serta salah dalam melakukan operasi hitung. 
Pada indikator keempat, persentase terendah yang diperoleh peserta didik yaitu dalam merepresentasikan bentuk gambar kebentuk matematis. Sebagian peserta didik tidak memahami gambar yang disajikan sehingga keliru dalam menentukan persamaan yang digunakan untuk menyelesaikan soal.

Pada indikator kelima, persentase terendah yang diperoleh peserta didik yaitu dalam merepresentasikan bentuk grafik kebentuk matematis. Sebagian peserta didik tidak memahami arti dari grafik yang disajikan sehingga keliru dalam menuliskan persamaan untuk menyelesaikan soal. Hal ini relevan dengan temuan Nur (2020) menemukan bahwa 2 dari 6 responden yang merasa kesulitan dalam menyelesaikan soal yang disajikan dalam bentuk grafik dan merasa kesulitan dalam mengartikan grafik tersebut. Penelitian yang dilakukan oleh Arifian, dkk (2018) juga menemukan bahwa pengalaman sulit yang dialami peserta didik adalah membuat grafik, menemukan persamaan matematis dari grafik dan membuat kesimpulan dengan verbal yang baik.

Korelasi kemampuan multi representasi terhadap hasil belajar peserta didik tidak ditemukan dalam penelitian ini. Hal ini tidak relevan dengan temuan Bagas (2019) yang menemukan bahwa terdapat korelasi yang signifikan (positif) antara variabel hasil belajar dengan variabel kemampuan multi representasi dengan koefisien korelasi sebesar 0,573 yang tergolong sedang. Penelitian oleh Siti dan Wawan (2018) juga menemukan bahwa terdapat peningkatan hasil belajar dengan menerapkan pendekatan multi representasi. Hal ini juga sesuai dengan fungsi multi representasi yang ketiga yaitu memperdalam pemahaman konsep (Ainswort, 1999). Dalam memahami konsep usaha, peserta didik harus mengerti fenomena yang disajikan secara verbal. Multi representasi dapat digunakan sebagai penunjang bagi pembelajar dalam membentuk pemahaman yang lebih baik terhadap suatu konsep yang mana hal ini akan berdampak pada hasil belajar peserta didik.

Tidak ditemukannya korelasi yang signifikan antara kemampuan multi representasi dengan hasil belajar disebabkan karena perbedaan jenis tes yang digunakan yaitu tes subjektif pada tes kemampuan multi representasi dan tes objektif pada tes hasil belajar. Perbedaan jenis tes yang digunakan dapat mempengaruhi hasil tes yang diperoleh, karena adanya perbedaan cara penskoran. Perbedaan skor yang dibuat antara tes kemampuan multi representasi dan tes hasil belajar dapat menyebabkan kesenjangan antara hasil kemampuan multi representasi dan hasil belajar yang diperoleh sehingga mengakibatkan data tidak berkorelasi. Berdasarkan penelitian terdahulu yang dilakukan Bagas (2019) dan Belka (2017) yang menggunakan instrumen dengan jenis tes yang sama menemukan bahwa terdapat korelasi yang signifikan dan positif antara kemampuan multi representasi dan hasil belajar.

\section{Kesimpulan}

Berdasarkan hasil penelitian, dapat disimpulkan secara umum bahwa kemampuan multi representasi peserta didik kelas XI IPA MA Negeri Bengkayang pada materi usaha tergolong rendah dengan rata-rata persentase sebesar 33,08\%. Hasil penelitian ini secara khusus dapat disimpulkan sebagai berikut: (1) penelian ini menemukan profil kemampuan multi representasi peserta didik untuk tiap tipe represntasi diantaranya: (a) representasi dari bentuk verbal ke gambar ( $\mathrm{V}-\mathrm{G}$ ) sebesar 12,50\%; (b) representasi dari bentuk verbal ke simbol ( $\mathrm{V}-\mathrm{s}$ ) sebesar 64,54\%; (c) representasi dari bentuk verbal ke matematis $(\mathrm{v}-\mathrm{m})$ sebesar 5,19\%; (d) representasi dari bentuk gambar ke verbal ( $\mathrm{g}$ v) sebesar 33,93\%; (e) representasi dari bentuk gambar ke simbol ( $g-\mathrm{s}$ ) sebesar 75,00\%; (f) representasi dari bentuk gambar ke matematis ( $\mathrm{g}-\mathrm{m})$ sebesar 8,93\%; (g) representasi dari bentuk grafik ke verbal $(\mathrm{gk}-\mathrm{v})$ sebesar 46,43\%; (h) representasi dari bentuk grafik ke simbol ( $\mathrm{gk}-\mathrm{s}$ ) sebesar 33,33\%; dan (i) representasi dari bentuk grafik ke matematis (gk-m) sebesar 17,86\%. (2) Penelitian ini menemukan tidak terdapat korelasi yang signifikan antara kemampuan multirepresentasi peserta didik dengan hasil belajar, dimana nilai $\left(r_{\text {hitung }} 0,04<r_{\text {tabel }} 0,4828\right)$ dan nilai signifikansi (2tailed) sebesar 0,982 $(>0,05)$. Penelitian selanjutnya diharapkan dapat meneliti secara intens tentang penyebab tingkat kemampuan multi representasi peserta didik maupun korelasi kemampuan multi representasi dengan hasil belajar. 


\section{Referensi}

Ainsworth, Shaaron. 1999. The Functions of Multiple Representations. Computers \& Education, 33 (2): 131-152.

Andromeda, Belka. 2017. Analisis Kemampuan Multi Representasi Peserta didik pada Konsep-konsep Gaya di Kelas X SMAN 3 Pontianak. Jurnal Pendidikan dan Pembelajaran Khatulistiwa, 6 (10).

Azwar, A dan Prihartono, J. (1987). Metode Penelitian Kedokteran dan Kesehatan Masyarakat. Jakarta: Binarupa Aksara.

Dienyati, N H. dkk. (2020). Analisis Pemahaman Konsep Siswa Berdasarkan Multi Representasi Pada Materi Usaha dan Energi Kelas XI SMAN 1 Banawa Tengah.Jurnal Kreatif Online, 8 (1).

Dimas, Arifian, dkk. (2018). Analysis Multiple representation Skills Of High School Students On Simple Harmonic Motion. AlP Conference Proceedings, 2014 (1).

Fauzi, Reza. (2016). Remediasi Kesalahan Menyelesaikan Soal Usaha Energi Menggunakan Strategi Systematic Approach To Problem Solving Berbasis Multirepresentasi Di MA.Jurnal Pendidikan dan Pembelajaran Khatulistiwa, 6(10).

Goldin, G.A. (2002). Representation in Mathematical Learning and Problem Solving. Dalam L.D English (Ed). Handbook of International Research in Mathematics Education (IRME). New Jersey: Lawrence Erlbaum Associates.

Habibah, S dan Bunawan, W. (2018). Implementasi Pendekatan Multi Representasi pada Model Pembelajaran Inquiry Training untuk Meningkatkan Hasil Belajar Siswa pada Materi Pokok Usaha dan Energi. Jurnal Penelitian Bidang Pendidikan, 24 (1): 28-37.

Heuvelen, A. V dan Xueli, Zou. (2001). Multiple representations of work-energy processes. Americans Journal of Physics, 69 (2): 184-194.

Leigh, Gregor. (2004). Developing Multi-representational Problem-Solving Skills in Large, Mixed-ability Physics Classes. (University of Cape Town Department of Physics: Thesis).

Permendiknas. (2006). Standar Isi. Jakarta: Departemen Pendidikan Nasional.

Prakoso, B. E. (2019). Analisis Kemampuan Multi Representasi Peserta Didik Dalam Mengerjakan Soal Gerak Lurus Berubah Beraturan di Kelas X SMA Negeri 7 Pontianak. Jurnal Pendidikan dan Pembelajaran Khatulistiwa, 8 (6).

Puspendik. (2019). Laporan Hasil Ujian Nasional 2019. (online). (https://hasilun.puspendik.kemendikbud.go.id/\#2019!sma!daya serap!13\&01\&0007!a\&04\&T\&T\&1\&!3!\&, diakses 2 November 2019)

Sugiyono. (2018). Metode Penelitian Kuantitatif. Bandung: Alfabeta.

TMS, Haratua dan Sirait, Judyanto. (2016). Representations Based Physics Instruction to Enhance Student's Problem Solving. American Journal of Educational Research, 4 (1): 1-4.

Waldrip. B. dkk. (2006). Learning Junior Secondary Science through Multi-Modal Representations. Electronical Journal of Science Education Southwestern University Preview Publication, 11 (1): 87-107. 